\title{
Noted
}

\section{Horror stories confront journalists}

Restless Souls: Rebels, refugees, medics and misfits on the Thai-Burma border, by Phil Thornton. Bangkok: Asia Books, 2007, 220 pp. ISBN 9748303918

PHil thornton specialises $P$ in documenting the lives of oppressed ordinary people . Eight years ago he was attached to the University of the South Pacific journalism programme during the George Speight 'coup' doing human rights stories that few other journalists were touching.

The Australian journalist travelled with the internal refugees from the Muaniweni valley on the 'freedom bus' to their temporary home at the Lautoka Girmit Centre. His stories were compelling tales of terror and tragedy.

While staying with me in Fiji, he read Bruce Connew's classic tale (1999) about the six-decade-old ethnic Karen struggle for survival against the Burmese military regime.

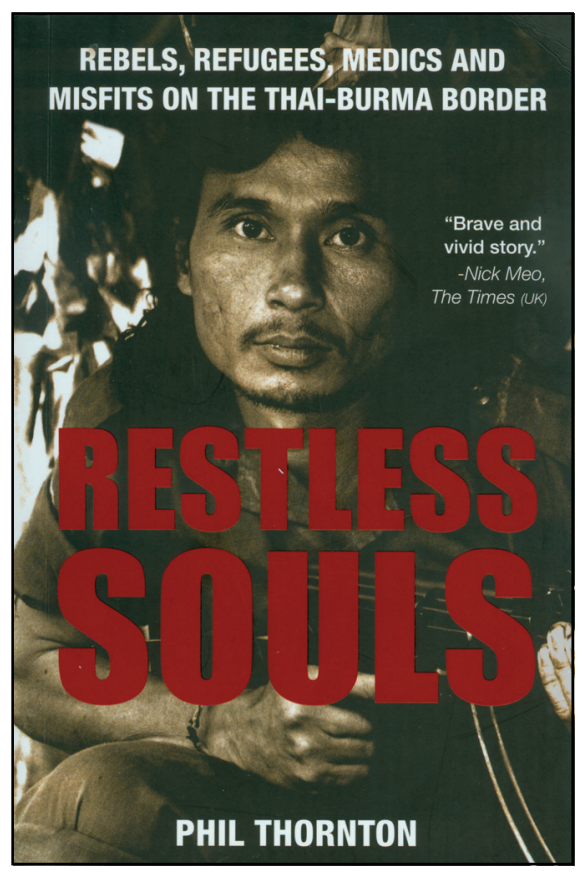

Little did I realise at the time the impact that this book would have on Thornton's life. He subsequently travelled to the Burma-Thai border zone.

Several years on, after countless illegal sojourns across the border in Karen territory, Thornton has produced his own book about the ignored conflict. And he still lives there.

In Restless Souls, Thornton provides colourful, evocative and tragic insights into the Karen people's struggle for freedom and the right to exist. He is based in part in the border town of Mae Sot - a bizarre community featuring aid peddlers, drug 
dealers, mercenaries, prostitutes, gem smugglers and freelance journalists.

Thornton paints a sympathetic picture of humanity against a backdrop of not only the tyranny of the Rangoon generals but also the Thai exploitation of the thousands of stateless people in the border refugee camps and illegal workers. But he is ruthless in his dissection of the aid and media flotsam.

Describing Mae Sot as a town 'full of rivalry as well as bribes', he says questions about who's who and who's doing what can be decidedly risky. The annual pre-Christmas coolness draws an influx of newcomers and opportunists into the local cafés:

Like kids trying to outscare each other, they all relay their best worst horror stories. Voices whisper and brag about decapitation, stolen camp funds, spies, extortion, gambling, guns, drugs, sex, corruption - bigger shadows to throw against the wall. (p. 114)

Thornton laments the Western media's fixation on Aung San Suu Kyi as the main news hook for reporting Burma while largely ignoring the Karen struggle: 'Her story can be simply told - in media shorthandas Beauty and the Beast.'

As for the huge, unregulated aid industry worth billions of dollars each year: 'Self-interest and selfpreservation drives NGOs as their humanistic ideals are pragmatically pushed aside. ... Disillusioned local staff label the workshops "rubberstamping exercises" to push unpalatable political policies' (p. 115).

One leading Karen advocate described aid consultants as 'like vampires sucking our blood ... I used to think [aid reports] would do something, but it's just another way of burying us' (p. 118). - DR DAVID ROBIE is director of the Pacific Media Centre.

\section{Reference}

Connew, B. (1999). On the way to an ambush. Wellington: Victoria University Press.

\section{'Model' a balanced approach}

\author{
Model Curricula for Journalism \\ Education for Developing Coun- \\ tries and Emerging Democracies. \\ Paris: UNESCO Series on Journalism \\ Education, 2007, 148 pp.
}

$\bigvee_{\text {schools teach? This remains }}^{\text {HAT }}$ a vexing question the world over, including the Pacific. A century after the first journalism school began in the United States in 1902, a clear formula for journalism education has yet to be defined. 